\title{
Mycoplasma-like Organisms Traversing Cell Walls in Cocos nucifera L., with Lethal Yellowing Disease
}

\author{
By A. BERYL BEAKBANE, MORWENNA M. FULLER \\ AND C. H. W. SLATER \\ East Malling Research Station, Maidstone MEI9 6BJ, Kent
}

(Received 2 February 1975)

\begin{abstract}
INTRODUCTION
The passage of complete mycoplasma-like organisms (MLOs) across sieve-plate pores has been studied in several plant species (Jacoli, I974; Leclant et al. I97I ; Parthasarathy, 1974; Shikata, Maramorosch \& Ling, 1969). We are not aware, however, of any published descriptions of fine filaments from mature MLOs traversing cell walls by passing through much narrower canals. The passage of such filaments through cell walls was observed in the present study.
\end{abstract}

\section{METHODS}

Specimens from coconut palms, Cocos nucifera $\mathrm{L}$., infected with lethal yellowing disease were sent to East Malling Research Station by the Coconut Industry Board's Coconut Research Station, Jamaica. Portions of leaf midrib were prepared for electron microscopy as described previously (Beakbane, Slater \& Posnette, 1972) and ultrathin sections of phloem tissue examined in an AEI EM 6B electron microscope.

\section{RESULTS AND DISCUSSION}

Very fine filaments extending from mature, spherical MLOs traversed cell walls through narrow canals, about $40 \mathrm{~nm}$ in width, present in thin zones of the sieve tube walls (Fig. I). The width of the cell walls within the zone traversed by the filaments was $250-300 \mathrm{~nm}$, while the width of the thicker regions of these walls was almost $600 \mathrm{~nm}$. The tripartite unit membrane of the filaments which passed through the canals appeared to be continuous with the membrane surrounding the MLO subtending it (Fig. I). During their passage across the walls, the filaments tended to break up into small, membrane-bound units emerging as complete elementary bodies (Fig. I). This method of translocation, combined with propagation of the MLOs, differs markedly from the translocation sequence described by Jacoli (1974) for MLOs passing through much larger sieve-plate pores. He postulates three phases of translocation: in the initial phase the MLO is carried by mass flow towards a sieve-plate pore and it changes its shape somewhat as it approaches the pore; the intermediate phase is characterized by the dumb-bell shape adopted by the MLO in the pore; in the withdrawing phase the MLO may leave a long appendix trapped in the pore. He suggests that it is unlikely that the dumb-bell-shaped structures were undergoing binary fission or fragmentation. The present study presents some evidence for the capacity of MLOs to traverse cell walls at sites other than sieve plates and, under these conditions, to multiply by producing elementary bodies by fragmentation during their passage through fine canals in sieve-tube walls.

We thank Mr D. Romney and Professor K. Heinze for supplying the coconut tissue. 


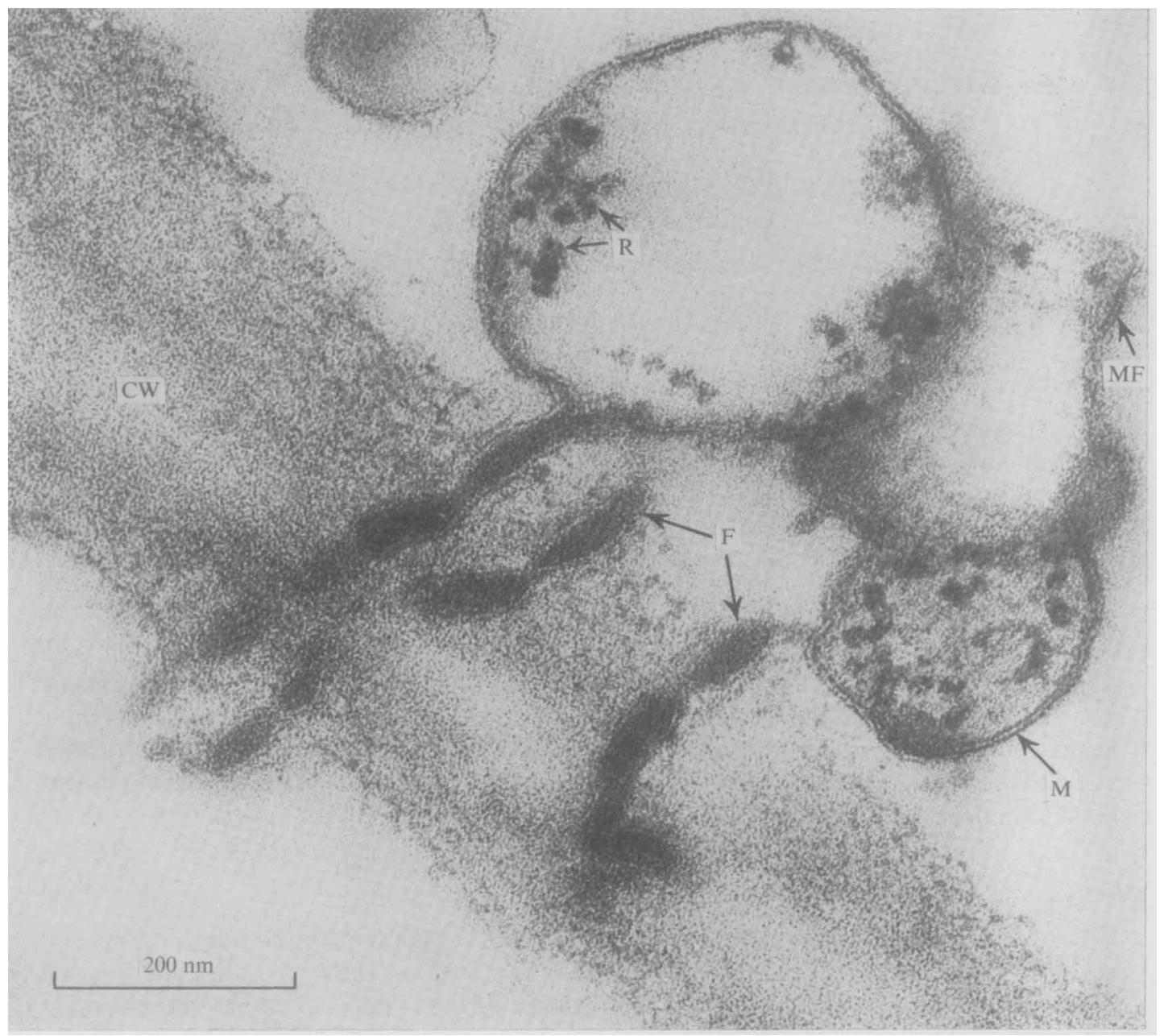

Fig. 1. Fine filaments arising from mature, spherical, mycoplasma-like organisms passing through fine canals in a phloem cell wall. The filaments appear to be breaking up into elementary bodies. $\mathrm{CW}$, Cell wall; $\mathrm{F}$, filaments; $\mathrm{M}$, tripartite unit membrane; MF, membrane fragment on degenerating MLO; $\mathrm{R}$, ribosomes.

\section{REFERENCES}

Beakbane, A. B., Slater, C. H. W. \& Posnette, A. F. (1972). Mycoplasmas in the phloem of coconut, Cocos nucifera L., with lethal yellowing disease. Journal of Horticultural Science 47, 265.

JACOLI, G. G. (1974). Translocation of mycoplasma-like bodies through sieve pores in plant tissue cultures infected with aster yellows. Canadian Journal of Botany 52, 2085-2088.

Leclant, F., Marchoux, G., Giannotti, J. \& Louis, C. (1971). Récherches sur une mycoplasmose affectant Lavandula hybrida. Comptes rendus hebdomadaire des séances de l'Académie des sciences 272, 2982-2985.

Parthasarathy, M. V. (1974). Mycoplasma-like organisms associated with lethal yellowing disease of Palms. Phytopathology 64, 667-674.

Shikata, E., Maramorosch, K. \& Ling, K. C. (1969). Presumptive mycoplasma etiology of yellows diseases. F.A.O. Plant Protection Bulletin 17, $12 \mathrm{I}-128$. 